\title{
Prediction of tsunami inundation impact in Padang city
}

\author{
Purnawan $^{1}$, Vera Surtia Bachtiart ${ }^{2}$, and Titi Kurniati ${ }^{3}$ \\ ${ }^{1}$ Department of Civil Engineering, Andalas University, Padang, Indonesia \\ ${ }^{2}$ Department of Environmental Engineering, Andalas University, Padang, Indonesia \\ ${ }^{3}$ Department of Civil Engineering, Andalas University, Padang, Indonesia
}

\begin{abstract}
Sumatera Barat has predicted by experts will be hit by earthquake due to subduction of IndoAustralian and Eurasian tectonic plates, this earthquake would result tsunami that will hit Padang city. The tsunami will cause inundation in the several areas of city near the coast. The area of tsunami inundation in Padang city has predicted by expert, this prediction result is displayed on a tsunami inundation map. This paper discusses the impact of tsunami inundation on housing and public facilities in those areas, this result could be used to prepare evacuation planning. The method of study, is by identification of impact tsunami inundation on housing and public facilities. This is carried out with superimpose of tsunami inundation map to Padang city map, submerged housing and public facilities are identified manually. The data then were verified in the field. From result of identification, the depth of inundation in subdistrict are classified, then the public facilities that affected by tsunami inundation are classified in each of subdistrict. Total 27.228 unit house and public facilities that affected by tsunami inundation, $86.3 \%$ is housing and $13.4 \%$ public facilities. The most affected subdistrict by tsunami inundation is Bungo Pasang, it is 2.899 house and public facilities submerged.
\end{abstract}

\section{Introduction}

Tsunami disaster in Aceh and Mentawai has increased government aware to prepare protecting facilities for people facing tsunami disaster. This is because the tsunami in Aceh has destroyed human, infrastructures and environment massively [1], see Fig 1 . The victim of tsunami disaster in Aceh is about 220.000 people, 654 villages were affected and 63.977 houses were displaced, also 14 countries were affected. The economic activities for several regions have stalled for sometime. Aceh is the city that has experiencing the most severe impact, this city was inactive almost for several months [2][3]. Heger and Neumayer reported that Aceh tsunami has negative impact on long-term economic growth, because tsunami has destroyed all infrastructure for support economic activities [4]. After both tsunami disasters, Indonesia Government recognize that this disaster should be handled properly, then Government include tsunami disaster in National Disaster Prevention Plan of Indonesia [5]. At the same time, Ministry of Energy and Mineral Resources of Indonesia have identified 19 locations that can be classified as tsunami prone zone [6]. Based on those informations, local Padang government has developed tsunami disaster prevention plan, important data that required for this program is a tsunami inundation map from the result of tsunami simulation. This map has been made by the expert and used by government as reference for several tsunami prevention plans. Based this map government has also determined several tsunami evacuation routes and shelters, this facilities is provided for people if tsunami disaster occur in Padang. Although government has build several evacuation facilities, however the impact of tsunami disaster is still unknown. This paper discusses a prediction impact of tsunami disaster in Padang.

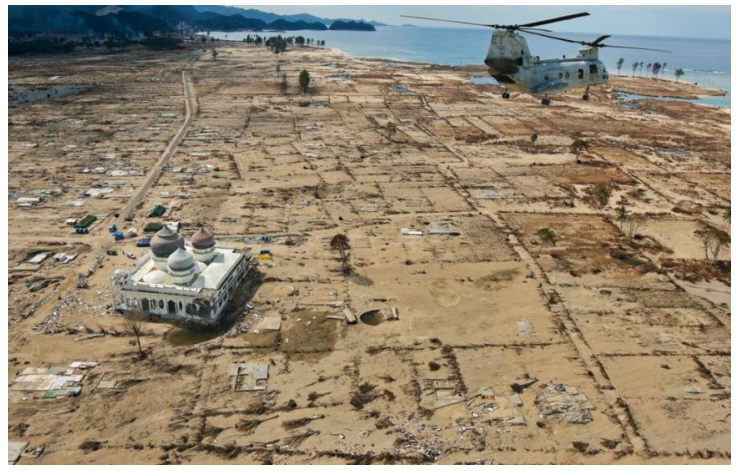

Fig 1. Impact of tsunami disaster in Aceh Source : Stanmeyer [1]

There are several studies which estimate the impact of tsunami disaster, Sugito et al produced tsunami damage map using tsunami inundation area map and mapping results of the tsunami run-up heights [7].

Goda et al [8] develop rapid method for estimation of tsunami loss based on inundation height and inundation area. The data were captured from remotely sensed images. Tsunami run up height and inundation was also

\footnotetext{
* Corresponding author: purnawan@eng.unand.ac.id
} 
used to produce vulnerability map and hazard assessment in Northeast coast of India by Mishra [9].

\section{Research Method}

Prediction of inundation impact to infrastructure in Padang was conducted by identification submerged infrastructure within area that affected by tsunami inundation. Infrastructures that identified were private and public infrastructure. Submerged infrastructure was identified from inundation map that used by government as reference for tsunami evacuation planning. Inundation map was marked into grid, then superimpose with aerial map. Infrastructures within a grid was identified and classified based on the sub district, number of submerged infrastructures, type of submerged infrastructures, depth of submerged infrastructures, inundation area at sub district and number of student and teachers that affected by inundation. Field verification of the data was conducted to ensure that the data was correct.

\section{Result and Discussions}

\subsection{Submerged Infrastructure}

Data analysis on inundation map that superimpose with aerial map, the impact of inundation could be counted. Fig. 2 shows the number of infrastructures that submerged at sub district in Padang.

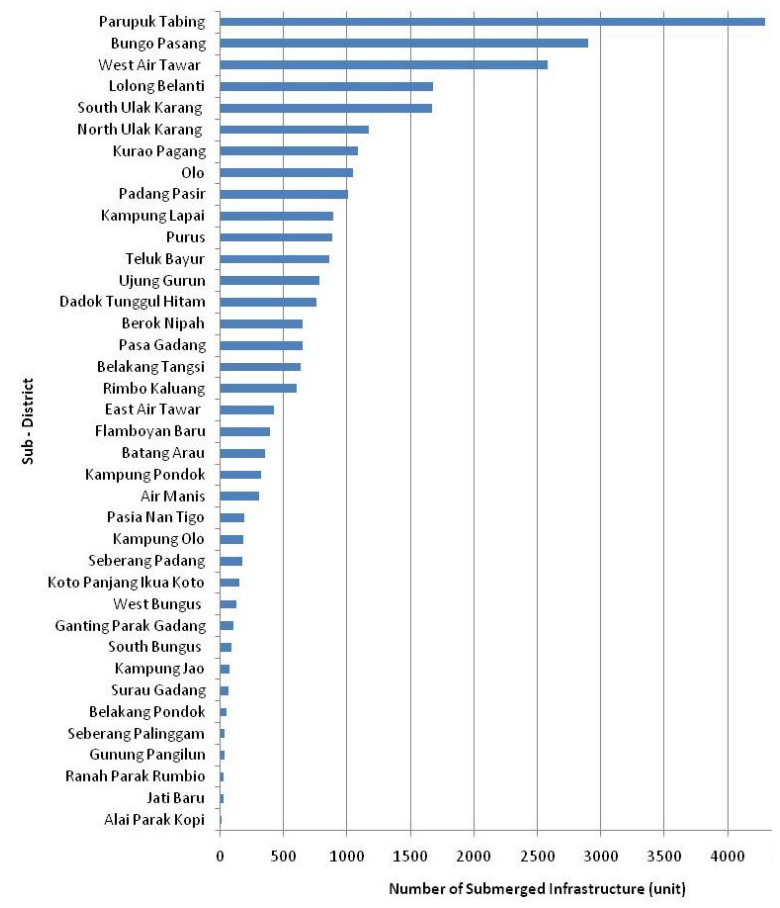

Fig 2. Number of infrastructures that submerged at sub district in Padang

Fig. 2 shows highest submerged infrastructures is at sub district Parupuk Tabing, it is about 4.298 unit, then followed by Bungo Pasang and West Air Tawar with submerged infrastructures about 2.899 unit and 2.599 unit. This sub districts are located at city areas that has high density housing areas. The lowest submerged infrastructures by tsunami disaster are located at sub district Alai Parak Kopi, this sub district is relatively far from tsunami prone zone.

In order to identify the infrastructure that submerged and give bad impact on human and environment, then the infrastructures that submerged more than $1 \mathrm{~m}$ were identified, the result is shown in Fig. 3.

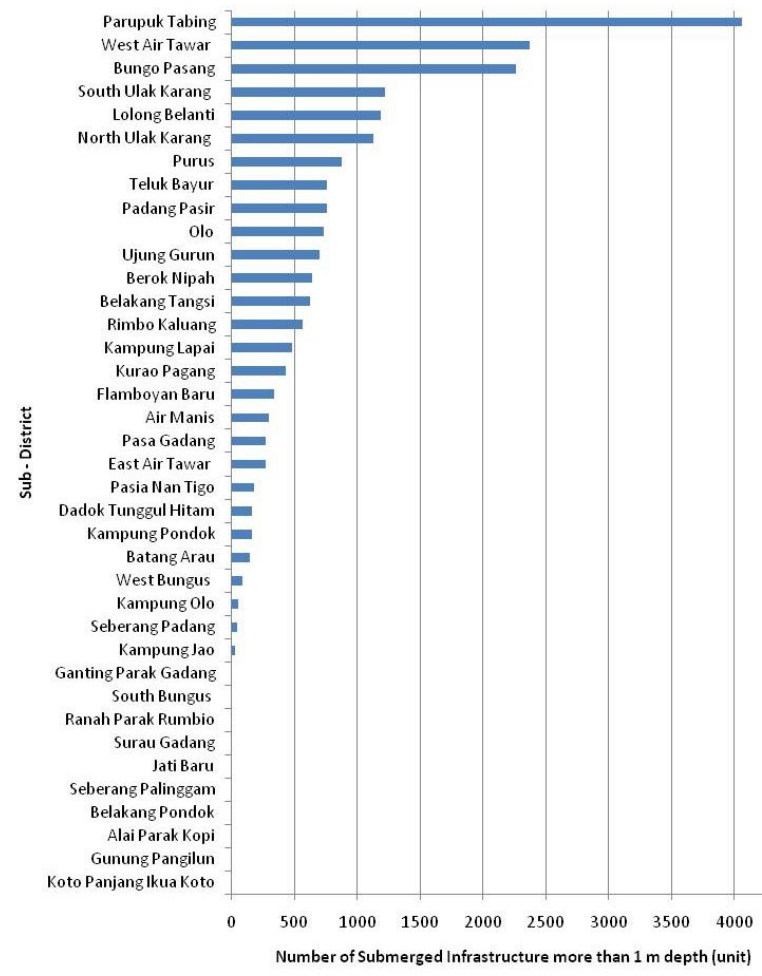

Fig 3. Number of infrastructures that submerged more than $1 \mathrm{~m}$ depth in sub district

From Fig. 3, it is shows the estimation number of infrastructures that submerged more than $1 \mathrm{~m}$ depth at sub district in Padang. The highest submerged infrastructures is at sub district Parupuk Tabing, it is about 4.066 unit, then followed by West Air Tawar and Bungo Pasang with submerged infrastructures about 2.374 unit and 2.265 unit. These three sub districts that should be paid more attention than other sub districts, because there are high number of infrastructure that affected by tsunami disaster. There are 10 sub district that has submerged infrastructures less than $1 \mathrm{~m}$, i.e. Ganting Parak Gadang, South Bungus, Ranah Parak Rumbio, Surau Gadang, Jati Baru, Seberang Palinggam, Belakang Pondok, Alai Parak Kopi, Gunung Pangilun and Koto Panjang Ikuo Koto.

Another data of different depth of submerged infrastructures have been identified, this data is required for evacuation management and estimation of the impact tsunami disaster to infrastructures. From analysis the data, the distribution of submerged infrastructures number at different inundation depths are obtained, it is shown in Fig. 4. 


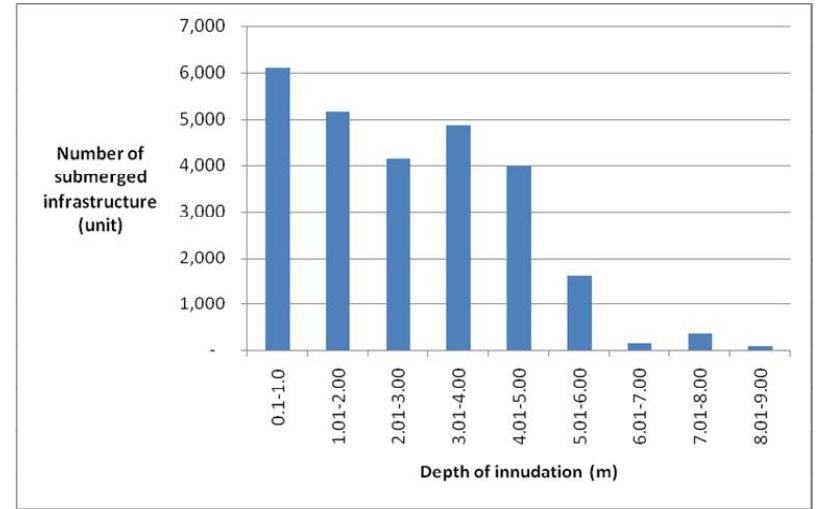

Fig 4. Number of infrastructures that submerged at tsunami inundation depth

From Fig. 4, it is shown that majority infrastructures are submerged more than $1 \mathrm{~m}$, although there are high numbers of submerged infrastructure less than $1 \mathrm{~m}$ available, but the infrastructure that submerged more than $1 \mathrm{~m}$ is dominant. This condition would difficult government to tackle the problem after tsunami disaster, because the infrastructures are possible destroyed by high tsunami wave.

The type information of submerged infrastructures by tsunami inundation is required to prepare the method of refugee evacuation and building restoration. Identification was carried out from aerial photo and verified in the field in every grid that is created, the result is revealed in Fig. 5.

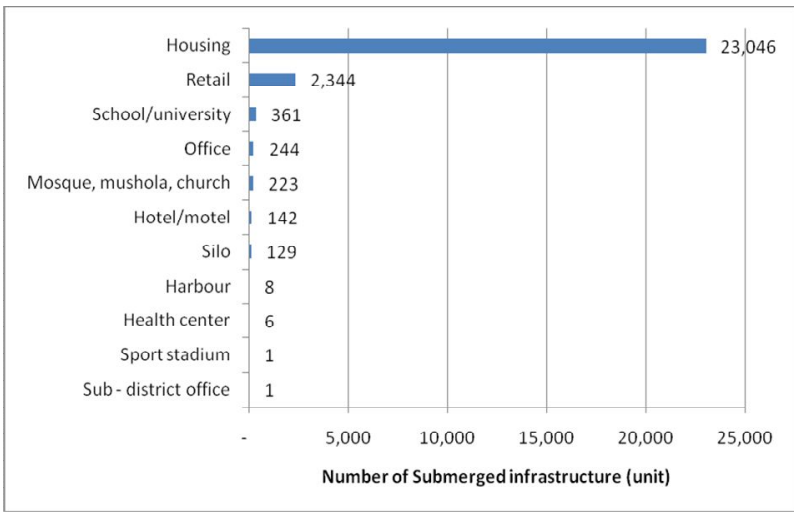

Fig 5. Type of infrastructures that submerged in Padang

Fig. 5 shows that houses are the most infrastructure that submerged by inundation of tsunami disaster, it is about 23.046 unit houses, and then followed by retail about 2.344 unit. The other infrastructure such as school/university, office, mosque and hotel are about 100 to 300 unit. The highest occupant at submerged infrastructure is university, because university has a lot student and staff.

\subsection{Inundation Area}

In order to identify the wide impact of tsunami disaster, the area of tsunami inundation was measured from inundation map using Autocad Card software in every sub districts, the result is shown in Fig. 6. This Fig. indicates that Parupuk Tabing sub district has the widest inundation area compared other sub district, this area is submerged about $9.5 \mathrm{~km}^{2}$. In this sub district, the number of submerged house is the highest one. Therefore, based on the impact on submerged infrastructures, Parupuk Tabing is a sub district that become the first priority area that should be prepared to facing the tsunami disaster. Other sub district has tsunami inundation relatively low compared Parupuk Tabing, and the lowest inundation area is at sub district Ranah Parak Rumbio, this sub district is about $2 \mathrm{~km}$ from the beach.

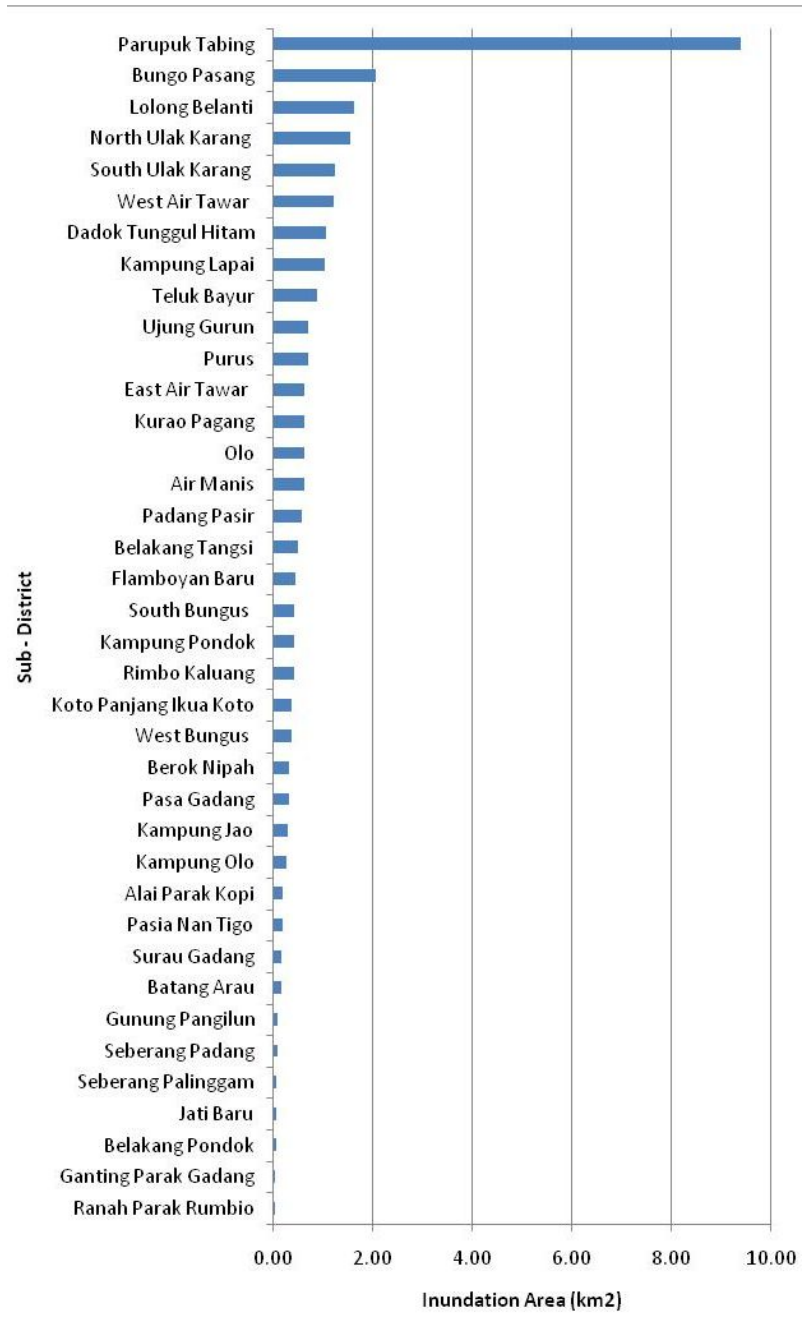

Fig 6. Inundation areas at sub district in Padang

\subsection{Inundation impact on university and school}

Tsunami inundation in every sub district would impact on the university and school activities. Education activities would be stalled, the students and teachers will stay at home or shelther for temporary. Therefore, it is important to calculate the number of student and teachers that affected by tsunami inundation. The university and school at inundations areas are identified, then site verification was conducted. The number of student and teacher at those university and school that submerged are calculated. The result of analysis is revealed in Fig. 7. From this Fig., it is shown that Universitas Negeri 
Padang is the submerged infrastructure that has the KBP. highest number of student and teacher, followed by STIE

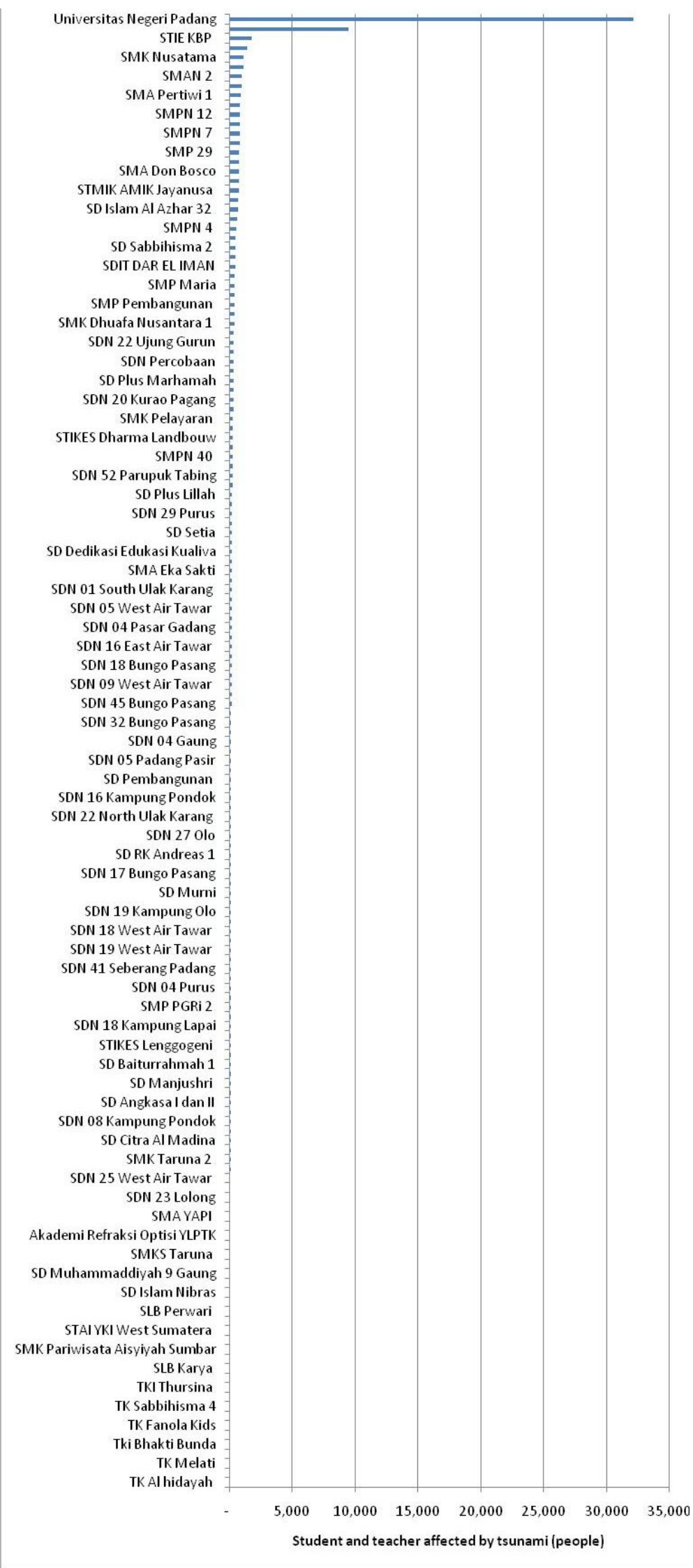

Fig 7. Number of students and teachers that affected by tsunami inundation 
Analysis of the data shows that the impact of tsunami disaster could affect the usage of infrastructures especially at tsunami prone zone. Economic and social activities would halted by this disaster. To reduce the possible impact of tsunami disaster, government could learn from tsunami disaster management from other countries. Davis et al reported that information of tsunami prediction from earthquake could be used as strategy to enhance disaster preparedness and reduce the impact of tsunami disaster that could occur [10]. Other method, ICT and wireless sensor networks are as useful alert tools to avoid devastating impact of tsunami disaster [11]. Japan Government establish recovery policies after Tohoku tsunami in 2011, it is structural/non-structural coastal protection facilities, land use regulations and emergency management [12].

\section{Conclusions}

From the analysis, it can be concluded that tsunami disaster would cause severe impact to infrastructure at tsunami prone zone, about 27.228 unit houses and public facilities that will be affected by tsunami inundation, $86.3 \%$ is housing and $13.4 \%$ public facilities. Total 155 university and school will be affected by tsunami inundation. This includes 84.986 student and teachers. The most affected sub district by tsunami inundation is Parupuk Tabing, this sub district has the highest number of infrastructure that is submerged and has the widest inundation area. Total infrastructure that submerged in this sub district is 4.298 , these are house and public submerged facilities. Based on this condition, comprehensive and integrated evacuation planning should be prepared to reduce negative impact of tsunami disaster in the future.
Acknowledgements, the author would like to thank Andalas University that funding this research with Contract No. 8/UN.16.17/PP.PGB/LPPM/2018.

\section{References}

1. J, Stanmeyer, National Geograpic, February, (2012) www.nationalgeographic.com

2. C,McCall, The Lancet, 384, 2095-2098, (2014) www.thelancet.com

3. R, Pramono, Thesis Dissertation. University of Indonesia, (2008)

4. M.P, Heger., E, Neumayer., Development Economics, 141, (2019)

5. National Disaster Prevention Agency, National Disaster Prevention Plan 2015 - 2019, (2014)

6. Ministry of ESDM, 19 Indonesia Region of Tsunami Prone. (2014). www.3.esdm.go.id.

7. N, Sugito., Y, Suzuki., N, Matsuta, Chapter $3.1-$ Understanding Spatial Variations of Tsunami Flooding. Disaster Resilient Cities - Concept and Practical Examples, 75-83, (2016)

8. K, Goda., N, Mori, T, Yasuda, International Journal of Disaster Risk Reduction, 40, (2019)

9. P, Mishra., T, Usha., Continental Shelf Research, 79, 16-22, (2014)

10. C, Davis., V, Keilis-Borok., V, Kossobokov., Soloviev, International Journal of Disaster Risk Reduction, 1, (2012)

11. M.U, Rahman., S, Rahman., S, Mansoor., V, Deep., M, Aashkaar, Procedia Computer Science, 65, 9299, (2016)

12. A.S, Correia, International Journal of Disaster Risk Reduction, 20, (2017) 